Jerzy Boryczka, Maria Stopa-Boryczka

\title{
CLIMATE OF THE EUROPE. PAST, PRESENT, FUTURE
}

\begin{abstract}
The advancing warming of Earth climate has largely been influenced by natural causes, i.e. increased Solar activity and decreasing volcanic activity on Earth. It still remains unknown which part of the warming process results from the increased amount of Solar energy reaching Earth surface, and which is being caused by the anthropogenic part of atmosphere's greenhouse effect. The facts speaking in favour of natural factors include synchronic changes of mean air temperature on the Northern hemisphere between 1856-2002, mean consecutive 11-year Wolf numbers, and the location of mass centres of the four biggest planets in our Solar system.

The theory of natural causes of climate warming is also backed by synchronic changes in carbon dioxide concentration and paleotemperature within the last 160,000 years and 450,000 years, recreated based Antarctica ice cores. Warmings occur every 100,000 years. They are triggered by increased Solar radiation in large geographic latitudes resulting from changes in Earth orbit and Earth axis slant (according to the already accepted Milankovic theory).

"Parallelism" of changes in $\mathrm{CO}_{2}$ concentration and paleotemperture shows that the atmospheric content of carbon dioxide is shaped by the amount of Solar radiation reaching Earth - through shifts in ocean waters temperature. It is more credible to claim that " $\mathrm{CO}_{2}$ concentration in atmosphere rises along with the amount of Solar radiation reaching Earth surface (i.e. when it is warmer)."
\end{abstract}

Key words: Solar radiation, temperature, greenhouse effect, spectre, volcanic platforms, Solar activity, planet mass momentum, forecast.

\section{INTRODUCTION}

The history of the Earth's climate can be divided into eras, depending on the time scale and the applied research methods, in the following way: 1. The last 3.5 billion years; 2. The last 2 billion years (Quaternary); 3. The last 10,000 years (Holocene), 4. The last few hundred years (historical, dendrometric and instrumental data).

Forms of relief of the postglacial surfaces, ancient coastal lines of seas, oceans and lakes, coral reefs and relicts of the first forms of life on the Earth inform us about the earliest history of the Earth. Deep-sea sediments, lake sediments and, above all, ice of the Antarctic and Arctic as well as mountain glaciers are the books in which the history of Earth's climate is written down.

Periods of cooling and warming of the climate are determined on the basis of palaeotemperature, that is, the content of the isotopes of oxygen ${ }^{18} \mathrm{O}$ or 
The more important events on the Earth

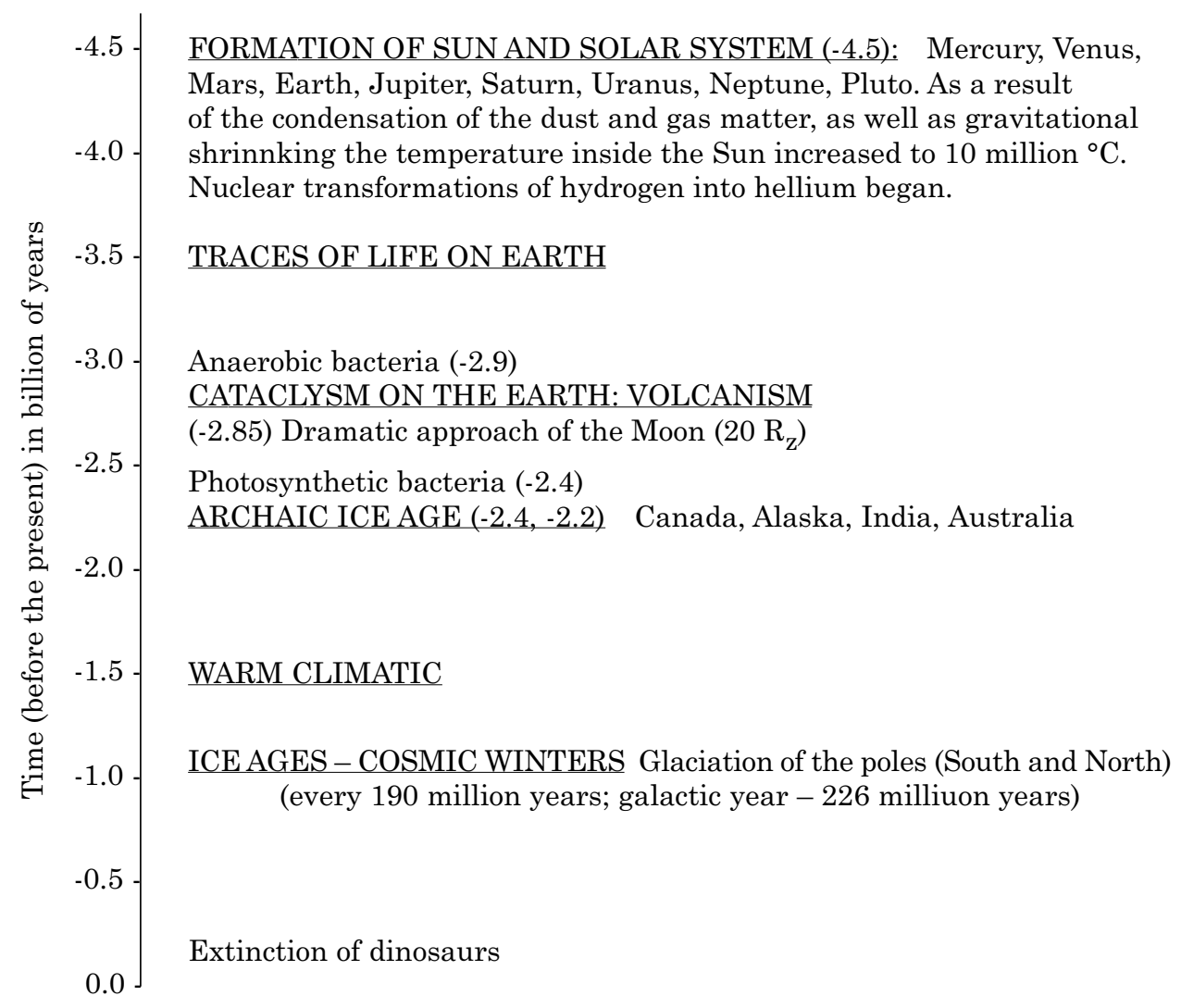

Fig. 1. The more important events on the Earth 3.5 billion years ago.

hydrogen ${ }^{2} \mathrm{H}$ (deuterium) in organic substances, deposited in sediments and ice cores. A fundamental importance for the reconstruction of the ancient climate has the establishing of the age of rocks, sediments and ice cores. To achieve this, the half-life of radioactive elements is used, namely that of the carbon isotope ${ }^{14} \mathrm{C}$ (5730 years) and of the isotopes originating in the decay of uranium: protactinium ${ }^{231} \mathrm{~Pa}$, thorium ${ }^{230} \mathrm{Th}$, uranium isotope ${ }^{234} \mathrm{U}$ and others, with half-life from ten to twenty thousand years.

Among the most important events in the history of the Earth (Fig. 1) in the last 3.5 billion years are traces of life: anoxygenic bacteria ( 2.9 billion years ago) and photosynthetic bacteria (2.4 billion years ago).

It was probably 2.9 billion years ago that a catastrophe happened on the Earth: the Moon and Earth approached each other very closely: as close as 20 times the Earth's radius (nowadays 60 times) (Panel and Mohr, 1970, after: Czapiewska, Bielicki, 1982). Heat created due to a great tidal force of Moon (27 times as large) caused strong volcanic eruptions on the Earth. The first 
traces of life come from 3.3-3.0 billion years ago. There is a coincidence of dates of, for example, disappearance of plutonium from the Earth's crust (2.92.4 billion years ago) and of the archaic volcanic activity.

About 2.3 billion years ago the volcanic activity decreased and the Earth's temperature decreased significantly. First (archaic) ice age took place on the Earth. An evidence of this are unique moraine deposits whose age is estimated to be 2.2-2.4 billion years. Traces of this archaic glaciation are preserved in Canada, Alaska, India and Australia. The archaic glaciation led to the creation of ice covers in the subpolar regions of both hemispheres.

\section{AN OUTLINE OF THE CLIMATE IN THE PAST GEOLOGICAL EPOCHS}

The Earth's climate depends on the changes in the intensity of shortwave radiation emitted by the Sun, on the absorption characteristics of the atmosphere (including $\mathrm{CO}_{2}$ ) and of the Earth's surface (albedo), as well as on the longwave radiation of the Earth.

During the last billion years six great ice ages occurred: 905, 750, 620, 440, 280, 3-2 million years ago (the Quaternary glaciation): on the average, every 190 million years. These are the so-called "cosmic winters", which may be caused by the revolution of the solar system around the centre of our galaxy (the Milky Way). The galactic year is equal to about 226 million years. A sudden warming and cooling of Earth's climate 55 million years ago might have caused the extinction of the dinosaurs.

During the last million years ten main cooling periods and ten warming periods of the climate occurred. The average period between the cooling periods (glaciations of the Earth) is equal to about 100,000 years.

Earth's glaciations (including Europe) were a consequence of the overlapping of the three long cycles: 92,000 years (eccentricity of the Earth's orbit), 40,000 years (the inclination of the Earth's axis with respect to the ecliptic plane) and 21,000 years (the location of the perihelion with respect to the point of the spring equinox) (Milankovič, 1938; Berger, 1988). Periodic changes of the parameters of the elliptic Earth's orbit caused then significant decreases of the solar radiation in large latitudes.

It turned out (Hays et al., 1976) that the oxygen isotope ${ }^{18} \mathrm{O}$ in the deposited calcium carbonate in deep-sea sediments is characterised by a similar periodicity: 100,000, 42,000 and 23,000 years.

A comparison of the changes of concentration of carbon dioxide and the palaeotemperature during the last 160,000 years, reconstructed on the basis of the chemical analysis of ice cores at the Vostok station (Fig. 2) (The Atmosphere..., 1990), with the changes of the solar radiation sums provides important information about the causes of climate changes. The global warming and the very high concentration of $\mathrm{CO}_{2}$ in the atmosphere which occurred 135,000 years ago coincided with the maximum of the solar radiation sums at the latitude $\varphi=65^{\circ} \mathrm{N}$ (from March through September), caused by the 


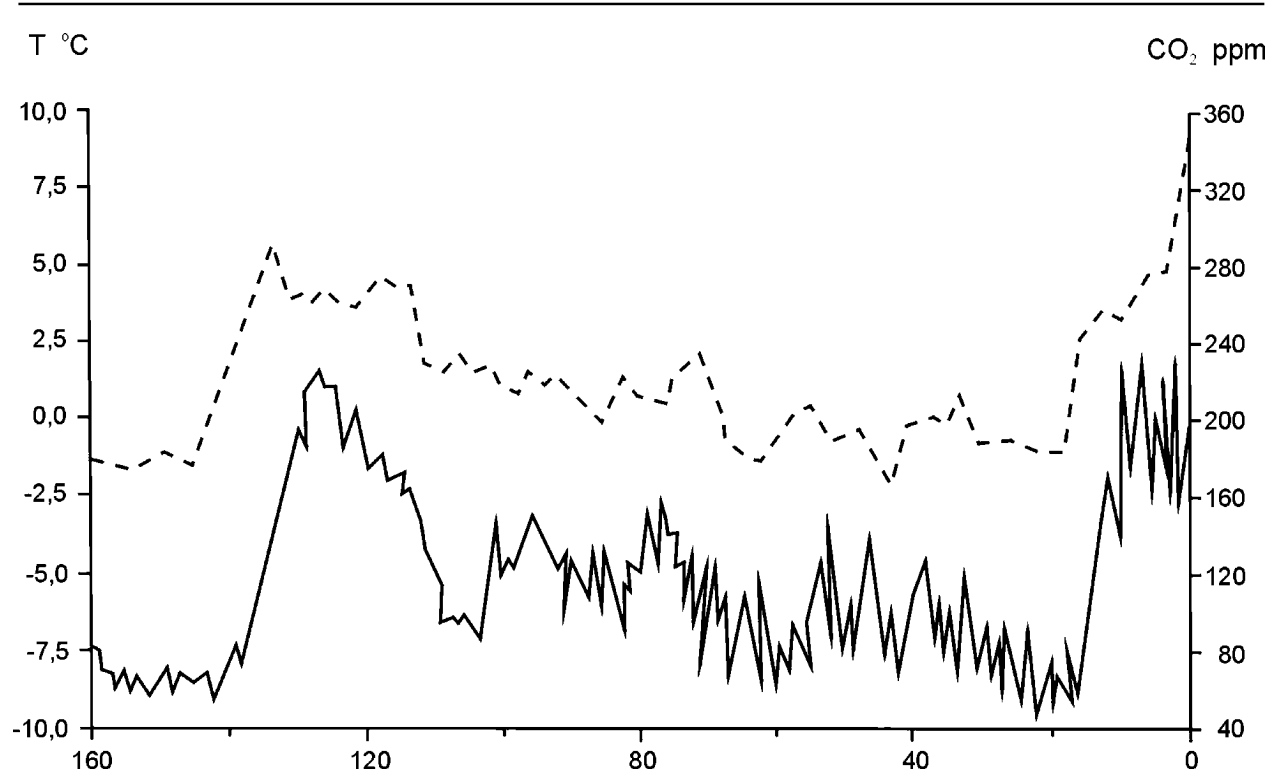

Fig. 2. Changes of $\mathrm{CO}_{2}$ concentration in the atmosphere (upper diagram) and of palaeotemperature (lower diagram) during the last 160,000 years, on the basis of ice cores at the Vostok station (WMO, 1990).

changes in the Earth's orbit (Fig. 3). The "parallel" occurrence of the changes in the radiation sums, palaeotemperature and the concentration of $\mathrm{CO}_{2}$ is an evidence that the content of $\mathrm{CO}_{2}$ in the atmosphere depends on the influx of the solar radiation to the Earth's surface (on the temperature of the ocean waters). Nowadays the tendency of the palaeotemperature to decrease corresponds to a distinct tendency of the $\mathrm{CO}_{2}$ concentration to increase.

Analogous conclusions follow from the comparison of the interglacial periods and the maxima of the concentration of $\mathrm{CO}_{2}$ in the atmosphere above the Antarctic during the last 400,000 years (Fig. 4) (Petit et al., 1999) with the changes of the solar radiation sums at the latitude $\varphi=65^{\circ} \mathrm{N}$ (from March through September) (Fig. 5). The dates of the consecutive main maxima of the solar radiation sums at the latitude $\varphi=65^{\circ} \mathrm{N}$ in these months agree with the dates of the consecutive interglacial periods (maxima of temperature shown in italics).

In calculations of the solar radiation sums on the parallel $\varphi=65^{\circ} \mathrm{N}$ from March through September the following periods were taken into accounts: $100,000,40,000$ and 21,000 years. It was assumed that the eccentricity $e$ of the elliptic orbit of the Earth during the cycle of 100,000 years varies from 0.00 to 0.066 (currently $e=0.017$ ), and the inclination $\varepsilon$ of the ecliptic to the equator during the cycle of 40,000 years, from $21^{\circ} 58^{\prime}$ to $24^{\circ} 36^{\prime}$ (currently $\left.\varepsilon=243^{\circ} 30^{\prime}\right)$.

The periods of cooling and warming of the climate occurring 10,000 years ago (in Holocene) are known from the research on organic substances (and 


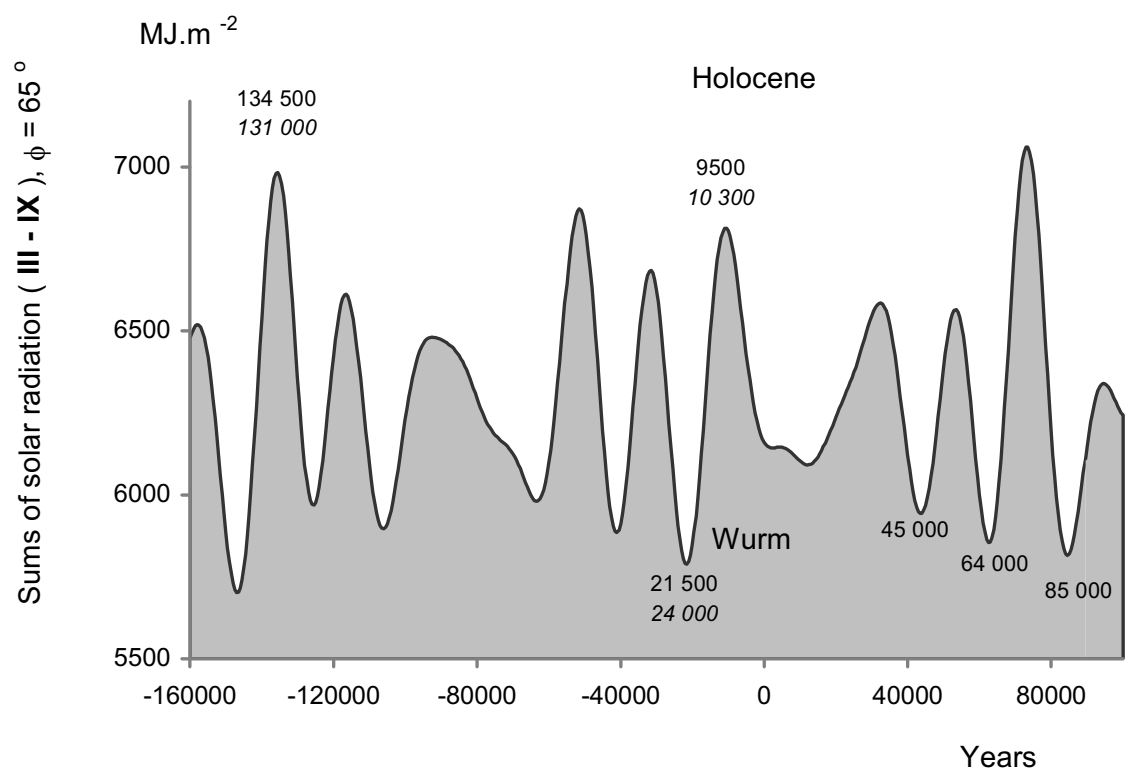

Fig. 3. Changes of solar radiation sums (from March through September) at the latitude $\varphi=65^{\circ} \mathrm{N}$ during the last 160,000 years (with a prediction for up to 100,000 years).
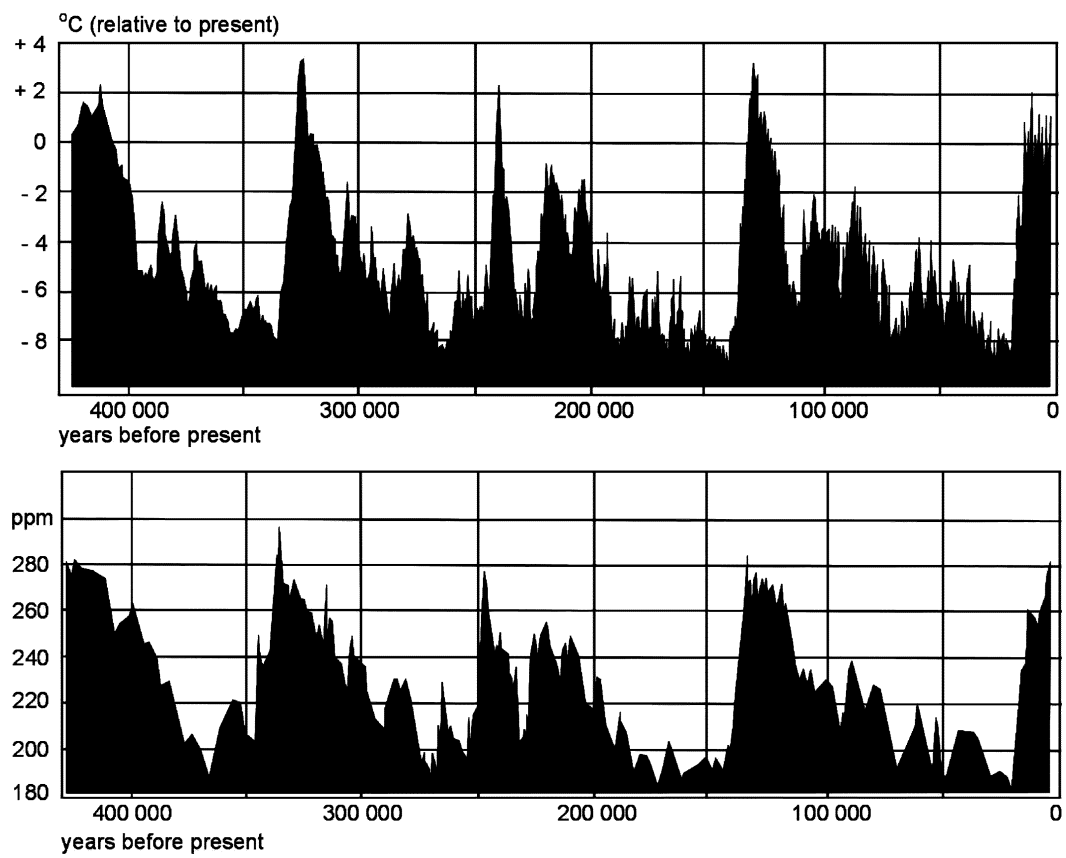

Fig. 4. Changes of air temperature in Antarctica and of $\mathrm{CO}_{2}$ concentration in the atmosphere during the last 400,000 years (Petit et al., 1999). 


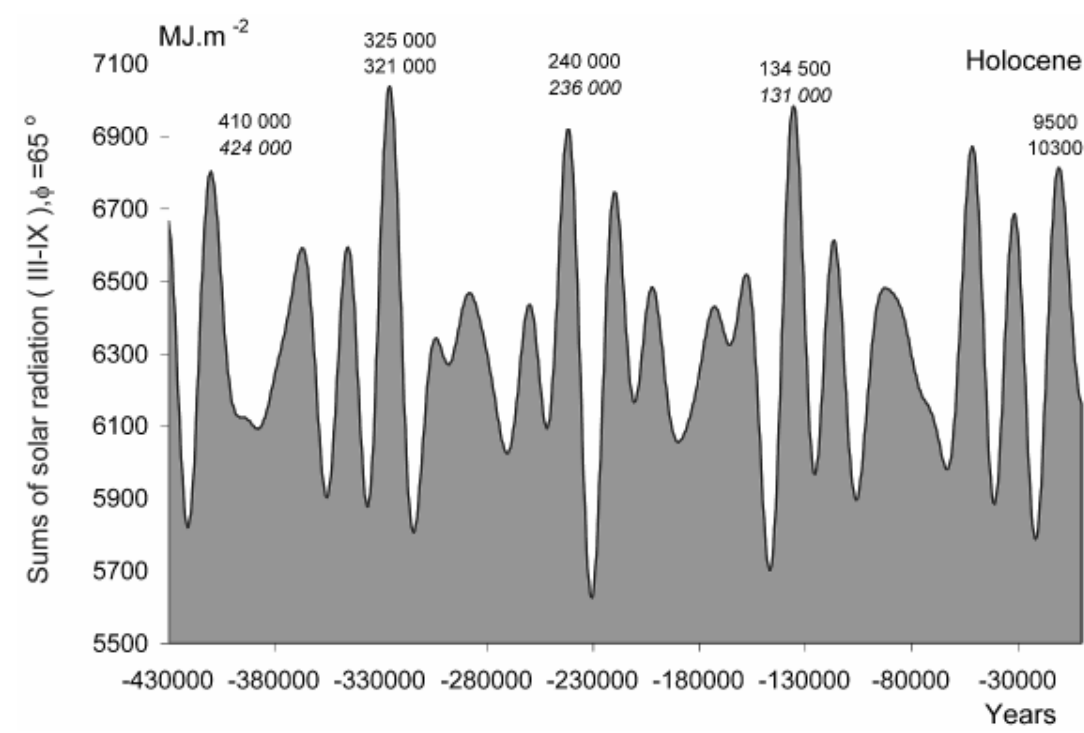

Fig. 5. Changes of solar radiation sums (from March through September) at the latitude $\varphi=65^{\circ} \mathrm{N}$ during the last 400,000 years.

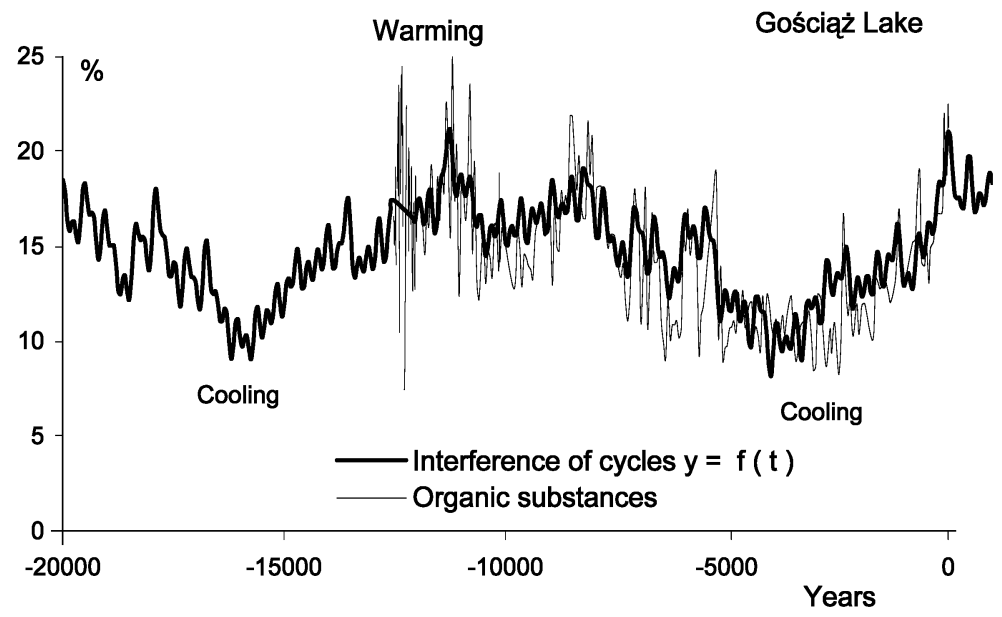

Fig. 6. Periods of warming and cooling of climate in Poland during the last 20,000 years, on the basis of the organic substances deposited in the sediments of Lake Gościąż (the line $y=$ $f(t)$ is the resultant of cycle interference).

the content of the oxygen isotope ${ }^{18} \mathrm{O}$ ) deposited in Lake Gościąz (Boryczka, Wicik, 1994). The periods of cooling and warming of Europe's climate correspond to the local minimal and maximal values of the changes in time $y=f(t)$ of the concentration of the organic substances in the sediments of Lake Gościąż (Fig. 6). The content of organic substances in the sediments in the period from $-20,000$ to $-12,540$ years ago was reconstructed from the 
interferences present in the spectrum of the following cycles: 50, 230, 360, $390,540,590,1120,1380,1770,2970,6080$ and 12,380 years. In the laminated sediments of Lake Gościąż it was possible to determine the calendar time (adding the yearly increases of the sediment cores). The main periods of cooling and warming of the climate during the last 20,000 years in Poland and in North America (Keree, Two Creeks) are synchronous.

The reconstruction of the air temperature in the surface layer of the atmosphere in various places on the Earth in the last millennium (based on reduction of the glaciers, width of the tree rings and direct measurements) indicates three basic time intervals: "mediaeval optimum" (800-1200), "little ice age" (1400-1900) and the current warming (from 1900).

\section{PERIODS OF COOLING AND WARMING OF THE CLIMATE IN RECENT CENTURIES}

During the last 400 years three main periods of cooling of Europe's climate occurred, with the smaller average global air temperature in the northern hemisphere around the years 1600, 1700 and 1830. The best investigated (on the basis on instrumental data) is the last one, the period of the greatest cooling in Europe. One should note that this period occurred during the three weakest and prolonged (12- to 13-year) cycles of solar activity (1798-1833), specifically during the weakest 13-year cycle of sunspots (1811-1823, during the absolute secular minimum since the year 1700).

The year 1811 was a special year as regards the situation of the solar system. The distance of the Sun from the centre of mass of the system was smallest (0.14 of the Sun's radius) and the acceleration of the Sun, greatest. This most recent period of global cooling of the climate (also in Poland) occurred during an intensified volcanic activity, after the most explosive volcanic eruptions, thus when the content of the volcanic dust in the atmosphere was very large, i.e., when the DVI coefficient was large (Lamb 1974): 1803, Cotopaxi $(\mathrm{DVI}=1100) ; 1815$, Tambora $(\mathrm{DVI}=3000) ; 1835$, Cosiguina $(\mathrm{DVI}=4000$, the absolute maximum).

The decrease of the direct solar radiation after the volcanic eruptions of Krakatau (Indonesia, 1883) and Hekla (Iceland, 1970) was of global character. After the eruption of the volcano Tambora (Indonesia, 1815) the dust reached the altitude of $60-70 \mathrm{~km}$. Volcanoes of the explosive type eject into the atmosphere large amounts of dusts and gases (HCL, $\mathrm{SO}_{2}, \mathrm{CO}_{2}, \mathrm{H}_{2}, \mathrm{~S}$ and others). Sulphate aerosols, which can remain in the stratosphere for as long as around 15 years, have the greatest influence on the scattering of solar radiation. They cause the warming of the stratosphere, while in the lower layers of the troposphere a cooling occurs, caused by the decrease of the radiation reaching the Earth's surface.

From the thermoenergy balance it follows that the decrease of the total radiation by as little as $1 \%$ with constant albedo cause the decrease of the average temperature near the Earth's surface by $1.2-1.5^{\circ} \mathrm{C}$. The decrease of 
the total radiation by $1.5-1.6^{\circ} \mathrm{C}$ may already lead to the glaciation of the Earth - from the poles to the equator (Sellers, 1962, Budyko, 1971).

One of characteristic features of the air temperature in Europe in the $19^{\text {th }}-20^{\text {th }}$ centuries is its periodicity with the periods equal to around 8,11 , 100 and 180 years. Air temperature cycles were determined by means of the method of "regression sinusoids" in the range of 2.0-200 years with the interval $\Delta \Theta=0.1$ years. This method of determination of the spectrum, elaborated in the Department of Climatology of the Warsaw University (Borycz$\mathrm{ka}, 1998$ ) consists in fitting the consecutive sinusoids (in accordance with the condition of smallest squares) with the equations $T=a_{0}+b \sin (2 \pi t / \Theta+c)$ with the variable period $\breve{C}$ to the results of the measurements. The sequence of the residual variance values $\varepsilon_{1}{ }^{2}, \varepsilon_{2}{ }^{2}, \ldots, \varepsilon_{\mathrm{n}}{ }^{2}$ is the so-called spectrum, with the local minima being the periods $\Theta$.

In Europe a period of air temperature with duration of around 8 years and large amplitudes $\Delta T=2 b=T_{\max }-T_{\min }$ (Table 1) dominates.

The range of oscillation of the air temperature in, for instance, Warsaw in the winter during the 8.3-year cycle is equal to $\Delta T=1.5^{\circ} \mathrm{C}$ and that of the yearly average (7.7-year period), $0.6^{\circ} \mathrm{C}$.

An 8-year period of the air temperature in Europe

Table 1.

\begin{tabular}{|l|c|c|c|c|l|c|c|c|c|}
\hline \multirow{2}{*}{ Locality } & \multicolumn{2}{|c|}{ Winter } & \multicolumn{2}{|c|}{ Summer } & \multirow{2}{*}{ Locality } & \multicolumn{2}{c|}{ Winter } & \multicolumn{2}{c|}{ Summer } \\
\cline { 2 - 6 } \cline { 7 - 9 } & $\Theta$ & $\Delta T$ & $\Theta$ & $T$ & & $\Theta$ & $\Delta T$ & $\Theta$ & $\Delta T$ \\
\hline Warsaw & 8.3 & 1.59 & 7.1 & 0.66 & Geneva & 7.7 & 0.62 & 7.8 & 0.40 \\
Cracow & 8.3 & 1.87 & 7.8 & 0.33 & Vienna & 8.3 & 0.87 & 8.4 & 0.38 \\
Wrocław & 8.3 & 1.53 & 7.8 & 0.27 & Rome & 7.9 & 0.30 & 8.4 & 0.32 \\
Lviv & 8.3 & 1.30 & 7.9 & 0.56 & Stockholm & 7.8 & 1.33 & 7.8 & 0.40 \\
Prague & 8.3 & 1.06 & 7.8 & 0.44 & Copenhagen & 7.8 & 1.24 & 8.3 & 0.51 \\
Berlin & 7.7 & 1.54 & 7.8 & 0.55 & Moscow & 7.9 & 0.76 & 8.3 & 0.60 \\
\hline
\end{tabular}

An 11-year period of the air temperature in Europe

Table 2.

\begin{tabular}{|l|c|c|c|c|l|c|c|c|c|}
\hline \multirow{2}{*}{ Locality } & \multicolumn{2}{|c|}{ Winter } & \multicolumn{2}{c|}{ Summer } & \multirow{2}{*}{ Locality } & \multicolumn{2}{c|}{ Winter } & \multicolumn{2}{c|}{ Summer } \\
\cline { 2 - 7 } \cline { 7 - 10 } & $\Theta$ & $\Delta T$ & $\Theta$ & $T$ & & $\Theta$ & $\Delta T$ & $\Theta$ & $\Delta T$ \\
\hline Warsaw & 11.6 & 0.53 & 11.3 & 0.22 & Geneva & 11.0 & 0.40 & 11.3 & 0.28 \\
Cracow & 11.3 & 0.84 & 11.4 & 0.26 & Vienna & 11.0 & 0.44 & 11.0 & 0.12 \\
Wrocław & 11.4 & 0.74 & 11.5 & 0.42 & Rome & 11.8 & 0.44 & 10.7 & 0.39 \\
Lviv & 11.2 & 1.11 & 10.7 & 0.06 & Stockholm & 11.3 & 0.29 & 11.6 & 0.38 \\
Prague & 11.0 & 0.42 & 11.1 & 0.19 & Copenhagen & 11.1 & 0.26 & 11.5 & 0.48 \\
Berlin & 11.0 & 0.42 & 11.6 & 0.18 & Moscow & 11.4 & 1.62 & 11.3 & 0.30 \\
\hline
\end{tabular}


The periodicity of the air temperature, with the period equal to around 11 years, has been known for a long time. This phenomenon is connected to the 11-year cycle of sunspots. In Table 2, periods of air temperature (around 11 years) and of amplitude $\Delta T\left({ }^{\circ} \mathrm{C}\right)$ in selected localities in winter and summer are shown.

The range of temperature fluctuations in this cycle (around 11 years) is generally over twice as large in the winter than in the summer.

In the measurement sequences of the air temperature in Europe one can find periods of around 100 and 180 years (Tables 3 and 4).

A 100-year period of the air temperature in Europe

Table 3.

\begin{tabular}{|c|c|c|c|c|c|c|c|c|c|}
\hline \multirow[t]{2}{*}{ Locality } & \multicolumn{2}{|c|}{ Winter } & \multicolumn{2}{|c|}{ Summer } & \multirow[t]{2}{*}{ Locality } & \multicolumn{2}{|c|}{ Winter } & \multicolumn{2}{|c|}{ Summer } \\
\hline & $\Theta$ & $\Delta T$ & $\Theta$ & $T$ & & $\Theta$ & $\Delta T$ & $\Theta$ & $\Delta T$ \\
\hline Warsaw & 113.4 & 1.22 & 75.0 & 0.88 & Basle & 85.5 & 0.14 & 87.6 & 0.64 \\
\hline Cracow & 90.0 & 0.48 & 88.0 & 0.67 & Copenhagen & 80.5 & 0.22 & 89.6 & 0.27 \\
\hline Wrocław & 123.3 & 1.66 & 75.0 & 0.50 & England & 99.3 & 0.44 & 102.5 & 0.20 \\
\hline Lviv & 108.8 & 1.30 & 74.1 & 1.33 & Stockholm & 86.3 & 0.55 & 89.4 & 0.51 \\
\hline Prague & 116.1 & 1.44 & 118.3 & 0.68 & Uppsala & 102.7 & 1.48 & 94.0 & 0.79 \\
\hline Vienna & 89.8 & 0.79 & 96.1 & 0.58 & Innsbruck & 69.9 & 0.80 & 84.6 & 0.50 \\
\hline
\end{tabular}

A 180-year period of the air temperature in Europe

Table 4.

\begin{tabular}{|l|c|c|c|c|l|c|c|c|c|}
\hline \multirow{2}{*}{ Locality } & \multicolumn{2}{|c|}{ Winter } & \multicolumn{2}{c|}{ Summer } & \multirow{2}{*}{ Locality } & \multicolumn{2}{c|}{ Winter } & \multicolumn{2}{|c|}{ Summer } \\
\cline { 2 - 5 } \cline { 6 - 10 } & $\Theta$ & $\Delta T$ & $\Theta$ & $T$ & & $\Theta$ & $\Delta T$ & $\Theta$ & $\Delta T$ \\
\hline Warsaw & 179.0 & 0,44 & 208.2 & 0.66 & Basle & - & - & 227.4 & 0.26 \\
Cracow & 163.8 & 0.43 & - & - & Copenhagen & - & - & 211.6 & 1.19 \\
Lviv & - & - & 195.3 & 1.00 & England & 166.9 & 0.48 & 204.6 & 0.34 \\
Geneva & 144.1 & 1.06 & 248.3 & 1.09 & Stockholm & 184.6 & 0.49 & - & - \\
Berlin & 212.8 & 1.18 & - & - & Uppsala & 182.3 & 2.50 & 192.8 & 0.39 \\
Rome & - & - & 224.9 & 1.40 & Innsbruck & 169.8 & 1.45 & - & - \\
\hline
\end{tabular}

Two main centres of the atmospheric pressure field exert a dominating influence on the climate of Europe (and of Poland): Icelandic Low and Azores High. These pressure centres related to the difference between the water temperature in the Northern Atlantic and that of the land show a negative correlation during the year. If the pressure in the Azores High decreases then the pressure in the Icelandic Low increases and vice versa. This is the socalled North Atlantic Oscillation (NAO). One of the measures of the zonal (parallel) circulation is the NAO index, defined by P.D. Jones and others (1997) as the standardised difference in pressure at sea level between 
Gibraltar and the southwestern Iceland. The NAO index in the years $1825-$ 2000 is characterised by the periodicity with the cycle equal to a few, around 15 and around 100 years (Table 5).

Table 5.

Periods $\Theta$ of the NAO index in the years $1825-1998$ ( $R=$ correlation coefficient $)$

\begin{tabular}{|c|c|c|c|}
\hline \multicolumn{2}{|c|}{ Summer } & \multicolumn{2}{c|}{ Winter } \\
\hline $\mathrm{Q}$ & $R$ & $\mathrm{Q}$ & $R$ \\
\hline 7,8 & 0,17 & 7,8 & 0,27 \\
10,3 & 0,20 & 8,3 & 0,24 \\
11,1 & 0,09 & 11,3 & 0,13 \\
13,8 & 0,14 & 15,5 & 0,17 \\
39,5 & 0,14 & 37,1 & 0,16 \\
83,2 & 0,17 & 105,1 & 0,17 \\
\hline
\end{tabular}

In the measurement sequences of the $N A O$ index in the winter a cycle of around 8 years dominates, similarly as it is the case for the air temperature.

\section{TENDENCIES OF CLIMATE CHANGES IN EUROPE IN THE $17^{\mathrm{TH}}-20^{\mathrm{TH}}$ CENTURIES}

The Earth's climate in the $19^{\text {th }}-20^{\text {th }}$ centuries underwent a systematic warming. The average global air temperature in the years 1890-1985 increased during the winters from $0.2^{\circ} \mathrm{C}$ near the equator to $5^{\circ} \mathrm{C}$ in the polar zone. The increase of the average global temperature, calculated on the basis of measurements of the air and sea surface temperatures in the years $1861-1991$ is equal, on the average, to $0.5^{\circ} \mathrm{C}$.

Table 6 (Boryczka, Stopa-Boryczka et al., 2003) shows the tendencies of the air temperature in Europe, determined according to the equations of the regression line $T=A_{0}+A t$ (directional coefficients $A$ are expressed in ${ }^{\circ} \mathrm{C} / 100$ years). These tendencies characterise the average increase of the air temperature during any 100-year period in the appropriate time intervals. In general, the air temperature in European cities tends to increase in the winter $(A>0)$ and decrease in the summer $(A>0)$.

In Europe it is above all winters that are getting increasingly warmer. For instance, in Warsaw in the years 1779-1998 winters were getting warmer by $1.1^{\circ} \mathrm{C}$ per 100 years while summers are getting colder by almost $0.1^{\circ} \mathrm{C}$. An even greater increase of the air temperature in the winter occurred in Cracow $\left(1.5^{\circ} \mathrm{C} / 100\right.$ years $)$ and in Moscow $\left(1.6^{\circ} \mathrm{C} / 100\right.$ years $)$. The average yearly air temperature increased in Warsaw by $0.6^{\circ} \mathrm{C}$, in Cracow by $0.8^{\circ} \mathrm{C}$ and in Moscow by $0.7^{\circ} \mathrm{C}$ per 100 years. 
Tendencies of the air temperature changes in some European cities $\left({ }^{\circ} \mathrm{C} / 100\right.$ years)

\begin{tabular}{|l|c|c|c|c|}
\hline \multicolumn{1}{|c|}{ Locality } & Period & Winter & Summer & Year \\
\hline Warsaw & $1779-1998$ & 1.12 & -0.06 & 0.58 \\
Cracow & $1827-1997$ & 1.48 & 0.31 & 0.82 \\
Wrocław & $1792-2002$ & 0.69 & 0.25 & 0.52 \\
Lviv & $1824-2002$ & 0.53 & -0.22 & 0.20 \\
Prague & $1771-1990$ & 0.25 & -0.25 & -0.02 \\
Berlin & $1769-1990$ & 0.32 & -0.39 & 0.13 \\
Geneva & $1769-1980$ & 0.51 & -0.40 & 0.51 \\
Vienna & $1775-2002$ & 0.69 & -0.08 & 0.27 \\
Rome & $1811-1989$ & 0.04 & -0.10 & 0.09 \\
Stockholm & $1756-1994$ & 0.86 & -0.08 & 0.46 \\
Copenhagen & $1768-1991$ & 0.94 & 0.05 & 0.55 \\
Moscow & $1779-2002$ & 1.65 & -0.15 & 0.68 \\
\hline
\end{tabular}

Simultaneously with the increase of the average global air temperature an increase of the sea level occurs: on the average, by $10-25 \mathrm{~cm}$ in the last century. The level of the Baltic Sea, according to the water level in Świnoujście in the years $1811-1990$, rises on the average by $4.5 \mathrm{~cm}$ per 100 years (Kożuchowski, Boryczka, 1977). The rising of the sea and ocean levels in the $19^{\text {th }}-20^{\text {th }}$ centuries is partly the result of the cubical expansion of water. The volume of the ocean water (not counting seas) is at present equal to 1379.4 million $\mathrm{km}^{2}$ and the average depth of the oceans, 3704 metres. A rise in the ocean level by $18 \mathrm{~cm}$ corresponds to the increase of the water temperature by $1^{\circ} \mathrm{C}$ (from $4^{\circ} \mathrm{C}$ to $5^{\circ} \mathrm{C}$ ).

The chronological sequences of Wolf numbers (numbers of sunspots) and of the values of air temperature show that the temperature during the maximal solar activity in the 11-year cycle is higher than during the minimal solar activity (the wood increase in forests is also larger: the tree rings are thicker). This results from the dependence of the distribution of heat on the Earth's surface on solar activity.

The influx of solar energy to the Earth's surface depends on solar activity. During the 11-year cycle of solar activity the solar constant varies. It is largest near the maxima of sunspots (Kondratyev and Nikolski, 1970). Shortterm changes in solar activity do not play a large role in the shaping of the Earth's climate because of a very slow penetration of heat to the deeper layers of the Earth. More significant are long cycles of solar activity (Boryczka, 1998): 102- and 187-year cycles. In these cycles, near the maxima, large amounts of energy accumulate in the deeper layers of the continents and oceans; this energy affects the general atmospheric circulation.

The tendency of the solar activity (intensity of its radiation), observed in the last two centuries, to increase might significantly contribute to the gradual 


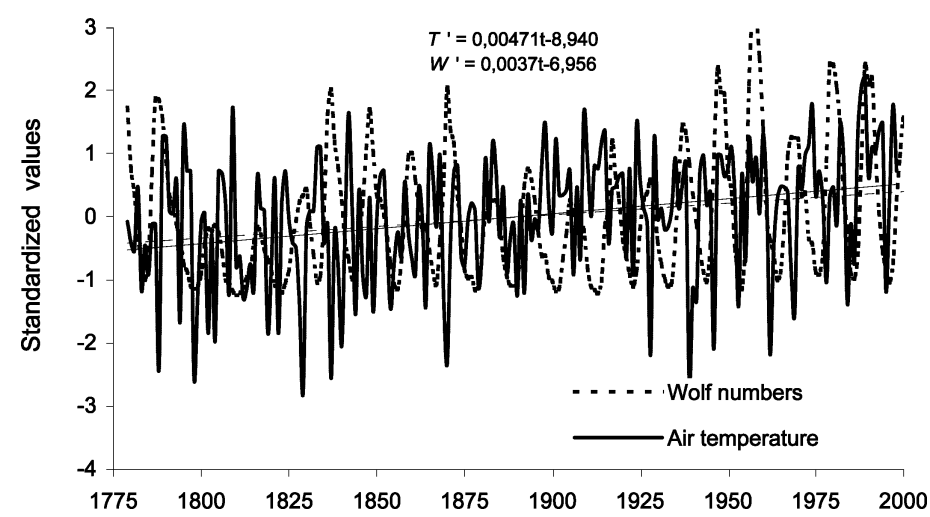

Fig. 7. Approximate equations of the Wolf number regression lines and of the air temperature in Warsaw in the years 1779-2000 (standardised values).

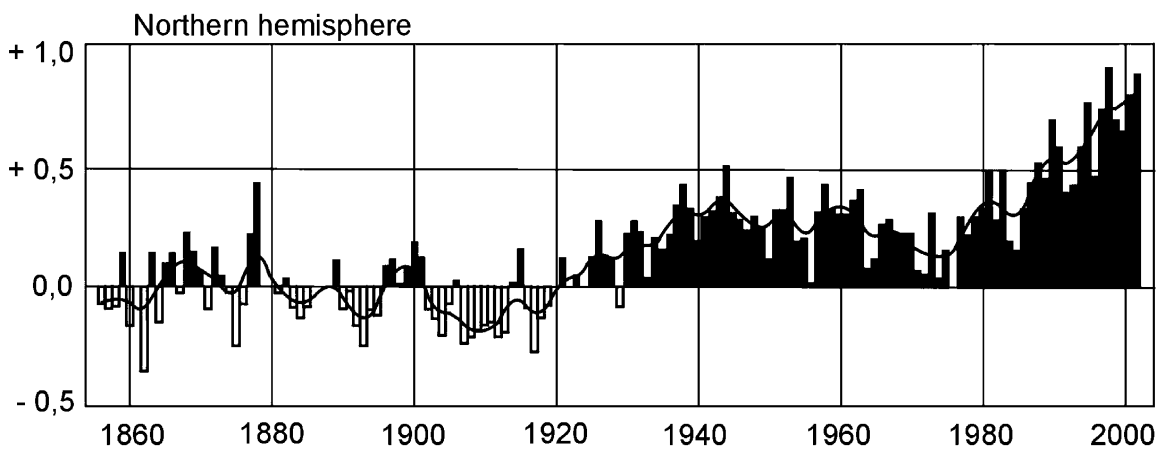

Fig. 8. Average yearly temperature in the Northern Hemisphere in the years 1856-2002 (deviations from the average for the years 1856-1900) (Bernes, 2003).

warming of the Earth's climate, through the changes in the overall at- mospheric circulation. This is evidenced, a.o., by the similar regression lines of the standardised values of Wolf numbers and of air temperature values in Warsaw in the years 1779-2000: $W^{\prime}=0.0037 t-6.956, T^{\prime}=0.0047 t-8.940$ (Fig. 7).

The dominating contribution of the solar radiation in the shaping of the Earth's climate in the gradual warming of the climate in the $19^{\text {th }}-20^{\text {th }}$ centuries is evidenced by the synchronic changes of the average air temperature in the northern hemisphere in the years 1856-2002 (Fig. 8) (Bernes, 2003) and of the consecutive averages of the 11-year Wolf numbers (Fig. 9). The deviations of the average air temperature from the average during the years 1856-1900 in the northern hemisphere are usually negative until 1920, while those after the year 1920 are positive. The years 1920-2002 are characterised by significant warming with the local minimum in the 1970s. The same is true in the case of the deviations of the consecutive averages of Wolf 


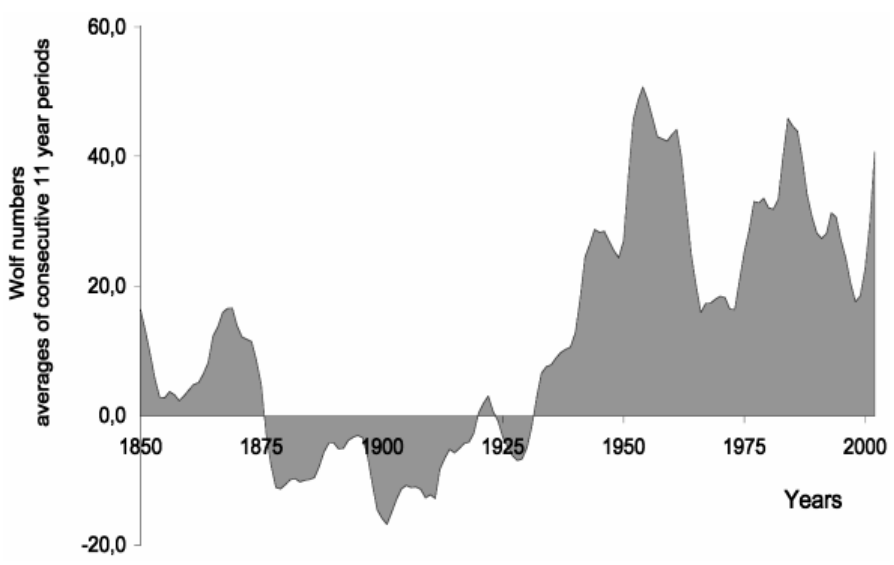

Fig. 9. Changes in solar activity (Wolf numbers) in the years 1856-2002 (deviations from the average for the years $1856-1900)$.

numbers for the same periods. Until 1925 they are negative while after 1925 , positive. The main local minimum of the Wolf numbers corresponds to the main local minimum of the temperature in the 1970s; solar activity in the years 1925-2002 is also much greater than before 1925 .

The demonstration of the dependence of the solar activity (Wolf numbers) on the changes in the location of the centre of mass of the four largest planets (Jupiter, Saturn, Uranus, Neptune) is of key significance for the discovering of the causes of the Earth's climate changes. The physical (as opposed to statistical) model describing adequately the changes in solar activity (Wolf numbers) in the years 1700-2002 (Boryczka, 2003) is a new concept in this field. The idea of searching for this dependence consists in a mathematical description of the (to a large extent unknown) physical interactions exerted on the Sun by the individual planets with the periods of revolution: 11.862 , $29.458,84.015$ and 164.79 years. In the descriptions of these interactions the shares of the consecutive planets in the variability of the mass momentum $M=\Sigma m_{i} r_{i}$ were isolated; that is, in the changes of the location of the centre of mass of the Solar system; the centre with respect to which the Sun moves. The modulation of the influences of the closer planets on the Sun by the farther planets, with longer revolution periods, was also taken into account.

It is interesting that the changes of the standardised consecutive averages of the 11-year Wolf numbers and of the consecutive averages of the 11-year values of the mass momentum $w_{i}=f\left(M_{i}\right)$ (Fig. 10) show a "parallel behaviour". It is possible that the four largest planets affect the changes of solar activity (probably by the change of the Sun's acceleration in its movement with respect to the centre of mass of the system). The demonstration of the dependence of the solar activity on the location of the centre of mass of the largest planets supports K.P. Butusov's hypothesis (1975) about the turbulent origins of sunspots, according to which sunspots are caused by the difference in the acceleration of the surface layers and central layers of the Sun. 


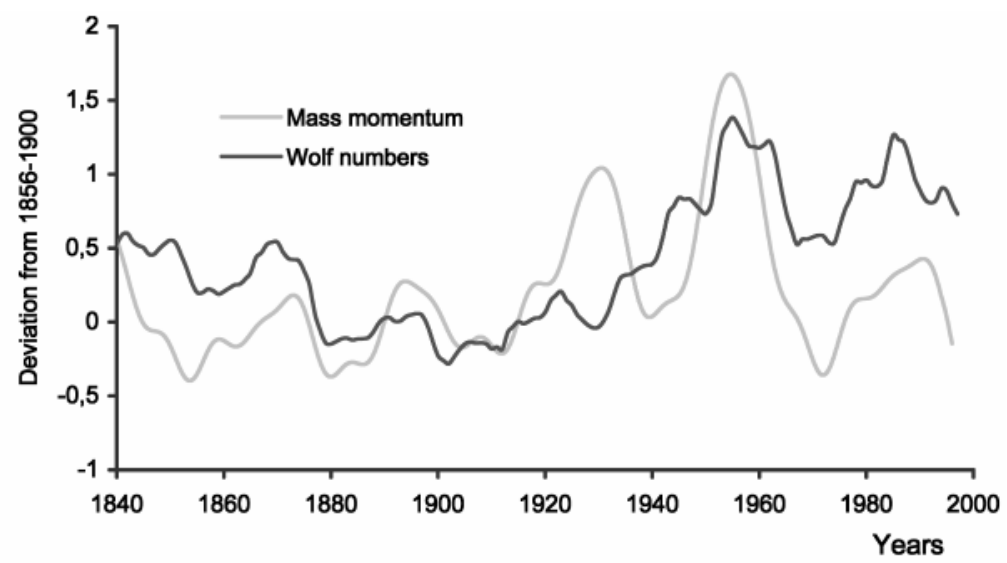

Fig. 10. Changes in solar activity (standardised Wolf numbers) and in the distance of the centre of mass (mass momentums) of the largest planets in the years 1856-2002 (consecutive average values over 11-year periods).
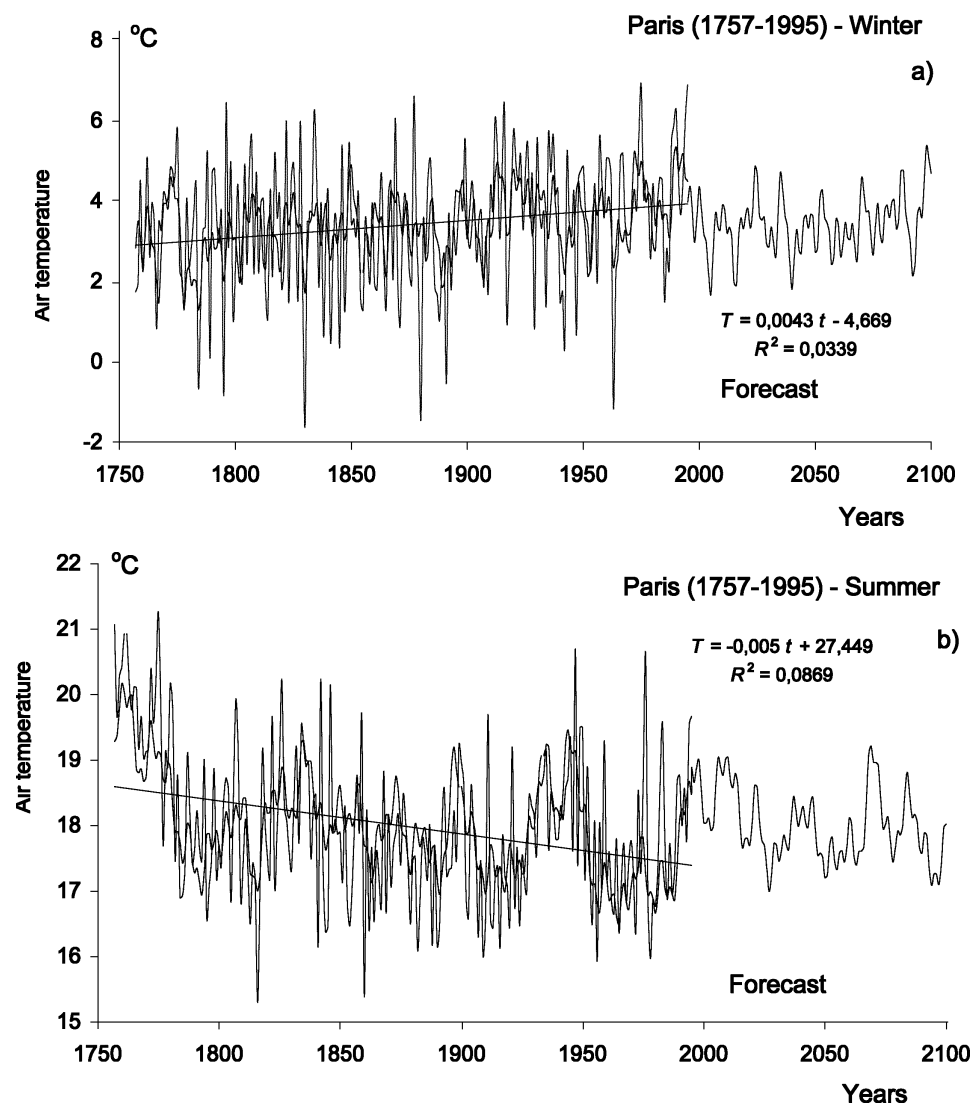

Fig. 11. Change of air temperature in Paris in the years 1757-1995: prediction for the years 1996-2100: a) winter, b) summer. 
It turns out that the contemporary periods of warming and cooling of the Earth's climate show a strong correlation with the maxima and minima of the measured mass of $\mathrm{CO}_{2}$ in the atmosphere, but a weak one with the emission of $\mathrm{CO}_{2}$ estimated on the basis of the amount of burned coal. R.H. Gammon (1984) claims that the course of the changes of the $\mathrm{CO}_{2}$ concentration in the atmosphere measured in the years 1958-1984 has three deep minima: in 1964, 1974 and 1983, in the vicinity of the dates of the minimal solar activity: $1964\left(W_{\min }=15.3\right), 1974\left(W_{\min }=27.6\right)$ and 1986 $\left(W_{\min }=2.0\right)$. According to him, these are oscillations corresponding to the absorption of $\mathrm{CO}_{2}$ by the oceans and the biosphere.

The main reasons of the climate warming in the $19^{\text {th }}-20^{\text {th }}$ centuries are: increase of solar activity, decrease of volcanic activity on the Earth in the $20^{\text {th }}$ century and the anthropogenic share of the greenhouse effect. It is not known, however, what is the contribution of each factor to the entire phenomenon.

The synchronic character of the changes of the sums of solar radiation reaching the Earth $\left(\varphi=65^{\circ}\right)$, palaeotemperature (determined on the basis of the oxygen isotope $\mathrm{O}^{16}$ or the hydrogen isotope $\mathrm{H}^{2}$ content in the Antarctic ice) and the concentration of $\mathrm{CO}_{2}$ in the atmosphere allows for the conclusion that the concentration of $\mathrm{CO}_{2}$ in the atmosphere is greater in the years when the influx of solar radiation to the Earth's surface is greater. Put it simply, the concentration of $\mathrm{CO}_{2}$ in the atmosphere is greater when the water in the oceans is greater, that is, when it is warmer in general.

\section{PREDICTIONS OF AIR TEMPERATURE CHANGES IN EUROPE IN THE $21^{\mathrm{ST}}$ CENTURY}

The verification of the similarity of the cycles of causes and results is of fundamental significance for the identification of the natural causes of the climate changes on the Earth. A demonstration of the analogous periodicity of the supposed causes, that is, of the astronomical variables (solar activity, parameters of the solar system) and of the results, that is, climatological variables (atmospheric circulation, air temperature) is essential.

Periods close to the periods of revolution of the four largest planets around the Sun and of their locations with respect to each other are present in the spectra of the variables listed above.

In the predictions it was assumed that the extreme values of the designated cycles with fairly large amplitude (statistically significant) would keep repeating as they did in the $18^{\text {th }}-20^{\text {th }}$ centuries. Such assumption is justified, a.o., by the 178.9-year planetary cycle. After 178.9 years, the values of the parameters of the solar system (distance of the mass centre US from the Sun, Sun's acceleration, resultant of the gravitational force of the planets) are repeated. The plots of the changes of the Wolf numbers (and of the solar constant) in the years $1700-1879$ and $1880-2000$, thus after 179 years, are almost identical. The time interval between the absolute maxima of Wolf 

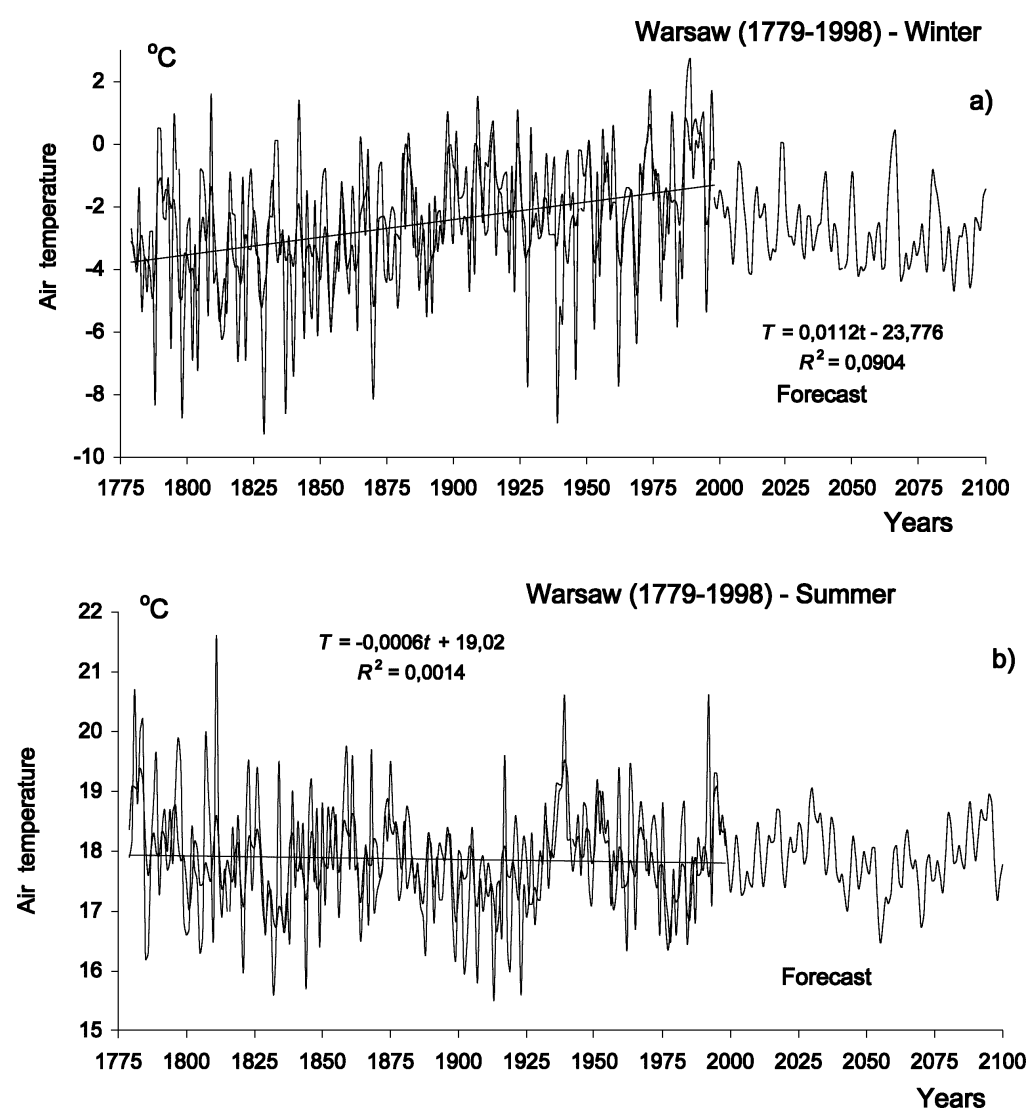

Fig. 12. Change of air temperature in Warsaw in the years 1779-1998: prediction for the years 1999-2100: a) winter, b) summer.

numbers $(1778,1957)$ is equal to 179 years. A 180-year cycle occurs many times in chronological sequences of the palaeotemperature (of the isotope ${ }^{18} \mathrm{O}$ ) and of the content of the substances in lake sediments from ten to twenty thousand years ago.

Prediction functions $T=f(t)$ are resultants of the inference of the statistically significant cycles $T=a_{0}+\Sigma b \sin (2 \pi t / \Theta+c)$. For instance, the prediction function of the average air temperature in Warsaw in winter is of the form:

$$
\begin{aligned}
T & =-2,54+0,542 \sin (2 \pi t / 3,31+0,5592)+0,669 \sin (2 \pi t / 5,2+0,5598)+ \\
& +0,488 \sin (2 \pi t / 7,1+2,4537)+0,832 \sin (2 \pi t / 8,3+2,5615)+ \\
& +0,483 \sin (2 \pi t / 12,9+1,1,2135)+0,455 \sin (2 \pi t / 15,3+1,1780)+ \\
& +0,458(2 \pi t / 18,1+1,8846)+0,260 \sin (2 \pi t / 22,5-2,6135)+ \\
& +0,312 \sin (2 \pi t / 39,6-2,5485)+0,263 \sin (2 \pi t / 73,8+2,0027)+ \\
& +0,511 \sin (2 \pi t / 113,4-2,9818)+0,156 \sin (2 \pi t / 179,0+2,0110)
\end{aligned}
$$



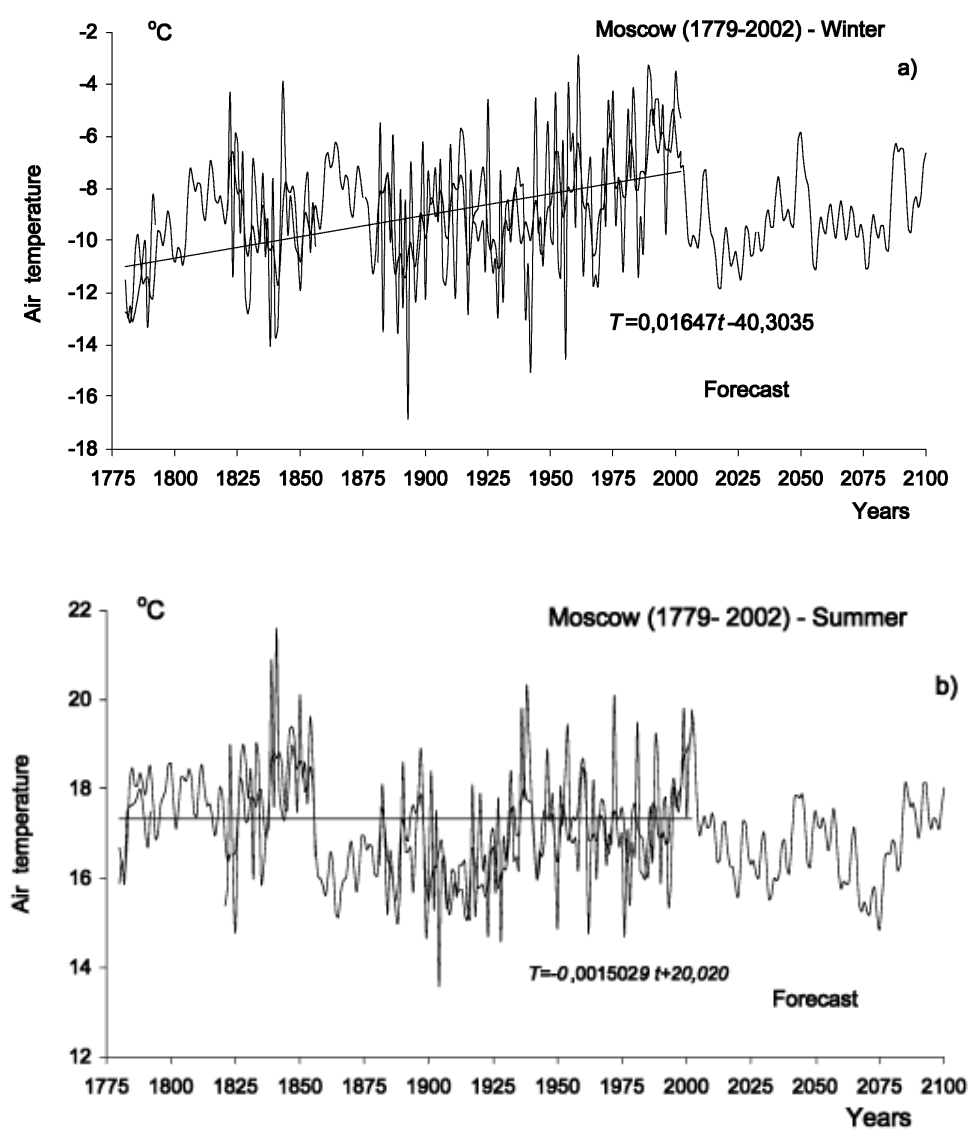

Fig. 13. Change of air temperature in Moscow in the years 1779-2002: prediction for the years 2003-2100: a) winter, b) summer.

An estimate of the accuracy of this prediction function for the air temperature in winter are: residual variance $\varepsilon^{2}=4.34$, special correlation coefficient $R_{s}=0.80$ and the standard error $\delta=2.21^{\circ} \mathrm{C}$. The changes of the air temperature in winter and in summer in Paris, Warsaw and Moscow are shown in Fig. 11-13. In the measurement intervals these are the values of the function approximating the function $T=f(t)$, while outside these intervals prediction values are given. Fig. 11-13 show also the measured values of the air temperature (in the winter and summer) in selected localities together with the regression lines. The coldest winters in Warsaw, with the average temperature from $-4^{\circ} \mathrm{C}$ to $-7^{\circ} \mathrm{C}$ will occur most likely in the middle of this century: around the year 2050 . They will be slightly milder than those in the beginning of the $19^{\text {th }}$ century, because of the gradually larger contribution of the anthropogenic factors. Colder summers (around $17.5^{\circ} \mathrm{C}-18.0^{\circ} \mathrm{C}$ ), on the other hand, will occur earlier, in the second decade of the $21^{\text {st }}$ century. 


\section{REFERENCES}

Berger A., Milankovitch M., 1988, Theory and Climate, Review of Geophysics, 26 (4). Bernes C., 2003, A Warmer World. The Greenhouse Effect and Climate Change, Monitor 18, Swedish Environmental Protection Agency, SWE CLIM.

Boryczka J., Wicik B., 1994, Record of Holocene Climatic Cycles in Lake Sediments in Central Poland, Miscellanea Geographica, vol. 6, Wyd. UW, Warszawa.

Boryczka J., 1998, Zmiany klimatu Ziemi [Changes of the Earth's Climate; in Polish], Wyd. "Dialog", Warszawa.

Boryczka J., 2003, Trends in Climate Change in Europe and Their Causes, in: Man and Climate in the 20th Century, (ed. J.L. Pyka et al.), Studia Geograficzne 75, Wyd. Uniwersytetu Wrocławskiego, Wrocław.

Boryczka J., Stopa-Boryczka M., Baranowski B., Kirschenstein M., Błażek E., Skrzypczuk J., 2003, Atlas wspótzależności parametrów meteorologicznych $i$ geograficznych $w$ Polsce, vol. XVII, Mroźne zimy $i$ upalne lata $w$ Polsce [Atlas of the Interrelationships of the Meteorological and Geographical Parameters in Poland, vol. XVII, Very Cold Winters and Very Hot Summers in Poland; in Polish], Wyd. UW, Warszawa.

Budyko M.I., 1971, Izmenenya klimata [Climate Changes; in Russian], Gidrometeoizdat, Leningrad.

Butusov K.P., 1972, K voprosu o cikličnosti solnečnoy aktivnosti. Solnce, električestvo žizni [On the Issue of the Periodicity of Solar Activity. Sun: Electricity of Life; in Russian], MGU, Moscow.

Gam mon R.H., Ste ele L.P., 1984, Global Distribution of Atmospheric Methane Determined from the NOAA/GMC Flask Network, in: Proc. of the USA-USSR Symposium on Atmospheric Trace Gases Effect Climate, Vilnius.

Hays J.D., I mbrie J., Shackleton N.J., 1976, Variation in the Earth's orbit: Pacemaker of the Ice Ages, Science, 194, No. 4270.

IPCC (Intergovernmental Panel in Climate Change, 19990), IPCC, 1995.

Kimbal N.N., 1980, Volcanic Eruptions and Solar Radiation Intensities, Mon. Wea. Review, vol. 46 , No. 8 .

Kondratev K.J., Nikolski G.A., 1970, Solar Radiation and Solar Activity, Quart. J. Royal Meteor. Soc., No. 96.

Kożuchowski K., Boryczka J., 1997, Cykliczne wahania i trendy czasowe zmian poziomu morza w Świnoujściu (1811-1990) [Cyclic Fluctuations and Temporal Trends of the Sea Level Changes in Świnoujście (1811-1990); in Polish], Przeglad Geofizyczny, XLII, No. 1.

La mb H.H., 1974, Volcanic Dust in the Atmosphere with a Chronology and Assessment of Meteorological Impact, Phil. Trans. Royal Soc., ser. A, 226.

Mila nkovič M., 1938, Matematičeskaya Klimatologiya i Astronomičeskaya Teoriya Kolebaniy Klimata [Mathematical Climatology and Astronomical Theory of Climate Fluctuations; in Russian], ONTU, Moscow.

Petit J.R., Jouzel J., Raynaud D. et al., 1999, Climate and Atmospheric History of the Past 420000 Years from the Vostok Ice Core, Antarctica, Nature 399, p. 429.

Reznikov A.P., 1982, Predskazaniye yestyestvennykh processov obučayuščeysya sistemoy [Prediction of Natural Processes by Means of a Self-Learning System; in Russian], Novosibirsk.

Sellers W.D., 1962, A Global Climate Model Based on the Energy Balance of the EarthAtmosphere System, J. Appl. Meteor., vol. 8.

The Atmosphere of the Planet Earth, 1990, WMO, No. 735.

English translation: Matgorzata Mikulska 